\title{
The association between oral anaerobic bacteria and acute myeloid leukemia
}

\author{
Mesut Öğrendik* \\ Consultant physician,Department of Physical Medicine and Rehabilitation, Uzunköprü State Hospital, Uzunköprü, Edirne, Turkey
}

\begin{abstract}
Porphyromonas gingivalis, Treponema denticola and Tannerella forsythia are associated with the pathogenesis of chronic periodontitis. The 'red complex' comprises of bacteria that are considered to be periodontal pathogens. These include $P$. gingivalis, T. Denticola and T. forsythia. Red complex secrete peptidylarginine deiminases (PADs). DNMT3A gene mutations have been observed in acute myeloid leukemia (AML). These mutations most often occur at position R882 in the methyltransferase domain of the gene. DNMT3A mutations are associated with poor overall survival. It has been observed that the codon 72 polymorphism of $\mathrm{p} 53$ has been significantly associated with AML cases compared to controls. The frequency of the homozygous Arginine genotype was significantly elevated in the AML group compared to the control group. The mutation of Lysine-39 of CCAAT/enhancer-binding proteins (C/EBPs) leads to impaired growth hormone-stimulated c-fos promoter activation The PADs of red complex may be associated with these mutations. P.gingivalis infection may be associated with the development and progression of AML, which represents a unique potential opportunity to reduce the incidence of AML by eradicating a common pathogen.
\end{abstract}

\section{Introduction}

Periodontal diseases are a group of disorders that affect the supporting tissues of the teeth. ${ }^{1}$ Periodontal diseases are common; for example, in a national survey in the United Kingdom, 79\% of dentate adults had bleeding gums, $88 \%$ had calculus, and $69 \%$ had periodontal pockets, including $10 \%$ with deep pockets [1].

\section{Oral anaerobic bacteria}

In periodontal diseases, the junctional epithelial tissue at the base of the gingival crevice migrates down the root of the tooth to form a periodontal pocket [1]. This movement is as a direct result of the microorganisms themselves and the indirect but potentially damaging side-effects of the host's inflammatory response to plaque accumulation. ${ }^{1}$ Individuals with periodontal disease have different predominant microflora than healthy individuals, but there is no single or unique pathogen associated with the diseases [1]. Most are Gramnegative and obligately anaerobic, except for capnophilic microflora which are associated with localized juvenile periodontitis. ${ }^{1}$ Although the microflora in periodontal disease are diverse, certain species are commonly found at sites undergoing tissue breakdown, including Porphyromonas gingivalis, Aggregatibacter actinomycetemcomitans, Tannerella forsythia, Prevotella intermedia, and Treponema denticola [1].

Among the Gram-negative bacteria isolated in high numbers from sites affected by periodontal disease, $P$. gingivalis has been shown to have the greatest proteolytic activity and to be the most virulent species inoculated in animals in a simple pathogenicity test [1]. The majority of this proteolytic activity has been characterized as gingipain, an argininespecific, cysteine protease [1]. Porphyromonas gingivalis, Tannerella forsythia, and Treponema denticola, collectively called the red complex, are the major pathogens responsible for chronic periodontitis and the secretion of peptidylarginine deiminases (PADs).

\section{Oral anaerobic bacteria and acute myeloid leukemia}

Acute myeloid leukemia (AML) is the most common form of acute leukemia affecting adults, and its incidence increases with age [2].

Somatic mutations in the DNA nucleotide methyltransferase $3 \mathrm{~A}$ (DNMT3A) gene have been identified in AML [3]. These mutations most often occur at position R882 in the methyltransferase domain of the gene.3 DNMT3A mutations are associated with poor overall survival [4].

It has been observed that the codon 72 polymorphism of $\mathrm{p} 53$ has been significantly associated with AML cases compared to controls [5]. The frequency of the homozygous Arginine genotype was significantly elevated in the AML group compared to the control group [5].

Approximately $8 \%$ of CCAAT/enhancer-binding proteins (C/ EBPs) are mutated in AML [6]. P. gingivalis also possesses a lysine protease [1]. The mutation of Lysine-39 in C/EBPs leads to impaired growth hormone-stimulated c-fos promoter activation [7]. The acetylation of Lys-39 in C/EBP beta plays a significant role in C/ EBPbeta-mediated transcriptional activation [7].

Oral bacteria peptidylarginine deiminases might lead to the $\mathrm{p} 53, \mathrm{C} /$ EBP, and DNMT3A mutations by degrading arginine and lysine.

\section{References}

1. Marsh PD, Martin MV (2001) Oral Microbiology. (4th Edn)Bodmin, MPG Books Ltd.

2. Estey E, Döhner H (2006) Acute myeloid leukaemia. Lancet 368: 1894-1907.[Crossref]

Correspondence to: Mesut Öğrendik, Consultant physician, Department of Physical Medicine and Rehabilitation, Uzunköprü State Hospital, Uzunköprü, Edirne, Turkey, Tel: 90-284-5131088,Fax: 90-284-5134020; E-mail: mogrendik@ hotmail.com

Received: July 10, 2017; Accepted: July 25, 2017; Published: July 27, 2017 
3. Ley TJ, Ding L, Walter MJ, McLellan MD, Lamprecht T, et al. (2010) DNMT3A mutations in acute myeloid leukemia. $N$ Engl J Med 363: 2424-2433.[Crossref]

4. Yuan XQ, Peng L, Zeng WJ, Jiang BY, Li GC, et al. (2016) DNMT3A R882 Mutations Predict a Poor Prognosis in AML: A Meta-Analysis From 4474 Patients. Medicine (Baltimore) 95: e3519.[Crossref]

5. Dunna NR, Vure S, Sailaja K, Surekha D, Raghunadharao D, et al. (2012) TP53 codon 72 polymorphism and risk of acute leukemia. Asian Pac J Cancer Prev 13: 347-350. [Crossref]
6. Quintana-Bustamante O, Lan-Lan Smith S, Griessinger E, Reyal Y, Vargaftig J, et al. (2012) Overexpression of wild-type or mutants forms of CEBPA alter normal human hematopoiesis. Leukemia 26: 1537-1546.[Crossref]

7. Ceseña TI, Cardinaux JR, Kwok R, Schwartz J (2007) CCAAT/enhancer-binding protein $(\mathrm{C} / \mathrm{EBP})$ beta is acetylated at multiple lysines: acetylation of $\mathrm{C} / \mathrm{EBPbeta}$ at lysine 39 modulates its ability to activate transcription. $J$ Biol Chem 282: 956-967. [Crossref]

Copyright: $@ 2017$ Öğrendik M. This is an open-access article distributed under the terms of the Creative Commons Attribution License, which permits unrestricted use, distribution, and reproduction in any medium, provided the original author and source are credited. 